\title{
O APROVEITAMENTO DE AREIA NA REGIÃO DO ALTO CURSO DO RIO IGUAÇU/PR: ASPECTOS GEOLÓGICOS, ECONÔMICOS E AMBIENTAIS
}

FÁBIO MARCELO MAGALHÃES

\author{
DISSERTAÇÃO DE MESTRADO - Programa de Pós-Graduação em Geologia - UFPR \\ DATA DE DEFESA: 05 set. 02
}

O propósito da pesquisa que resultou na elaboração desta dissertação de mestrado enfocou a caracterização dos principais depósitos de areia da região do alto curso do rio Iguaçu, a identificação das diferentes litologias que atuaram como área fonte dos sedimentos que constituem os depósitos e o levantamento dos empreendimentos de mineração. Neste estudo, foram analisados os equipamentos, a infra-estrutura e os métodos utilizados para a lavra e beneficiamento de areia, incluindo um levantamento da produção deste bem mineral e sua importância econômica para o estado do Paraná. A área estudada encontra-se no Primeiro Planalto ou Planalto de Curitiba, localizado entre a Escarpa Devoniana e a Serra do Mar, composto por rochas do embasamento Pré-Cambriano, entre elas os gnaisses, quartzitos, xistos, filitos, mármores calcíticos e dolomíticos. Estas rochas são cortadas por diques de diabásio e intrudidas por corpos ígneos alcalinos do Cretáceo, sendo que, na região de Curitiba, estão cobertas pela Bacia Sedimentar de Curitiba, de Idade Terciário - Quaternária. O domínio de rochas areníticas da Formação Itararé assenta-se sobre o embasamento cristalino e os depósitos recentes en- contram-se na planície aluvial dos maiores canais de drenagem, principalmente no rio Iguaçu. A atividade de explotação de sedimentos para emprego direto na construção civil da Região Metropolitana de Curitiba desenvolve-se no terraço fluvial do rio Iguaçu, municípios de Lapa a Balsa Nova, sendo realizada em cava seca, onde os depósitos recentes são explotados e os materiais são transportados para seleção em peneiras. A metodologia utilizada para o presente estudo consiste em cinco etapas principais: levantamento bibliográfico, trabalhos de campo, atividades de laboratório, tratamento e interpretação dos dados obtidos e redação da dissertação de mestrado. O estudo do aproveitamento do insumo mineral areia reveste-se de grande relevância para a Região Metropolitana de Curitiba, considerandose principalmente a dinamização do setor da construção civil. A pesquisa possibilitou estabelecer as relações entre mineração e o meio ambiente na região do alto curso do rio Iguaçu. Estas informações servirão como subsídios para o planejamento das atividades de pesquisa mineral com parâmetros atualizados, nesta importante área de produção de areia. 